Article

\title{
Evaluation of the Effect of Different Growth Media and Temperature on the Suitability of Biofilm Formation by Enterobacter cloacae Strains Isolated from Food Samples in South Africa
}

\author{
Mirriam E. Nyenje ${ }^{1}$, Ezekiel Green ${ }^{1}$ and Roland N. Ndip ${ }^{1,2, *}$ \\ 1 Department of Biochemistry and Microbiology, Faculty of Science and Agriculture, \\ University of Fort Hare, PMB X1314, Alice 5700, South Africa; \\ E-Mails: nyenjem@yahoo.com (M.E.N.); egreen@ufh.ac.za (E.G.) \\ 2 Department of Microbiology and Parasitology, Faculty of Science, University of Buea, Box 63, \\ Buea, Cameroon \\ * Author to whom correspondence should be addressed; E-Mail: rndip@ufh.ac.za or \\ ndip3@yahoo.com; Tel.: +27-782696191; Fax: +27-86624759.
}

Received: 20 May 2013; in revised form: 22 July 2013 / Accepted: 23 July 2013 /

Published: 9 August 2013

\begin{abstract}
This study evaluated the effects of growth medium, temperature, and incubation time on biofilm formation by Enterobacter cloacae strains. The ability to adhere to a surface was demonstrated using a microtiter plate adherence assay whereas the role of cell surface properties in biofilm formation was assessed using the coaggregation and autoaggregation assays. The architecture of the biofilms was examined under scanning electron microscope (SEM). All the strains adhered to the well of the microtiter plate when incubated for $48 \mathrm{~h}$, irrespective of the growth medium and incubation temperature. It was also noted that $90 \%$ and $73 \%$ of strains prepared from nutrient broth and cultured in brain heart infusion (BHI) broth and tryptic soy broth (TSB), respectively, were able to form biofilms, in contrast to $73 \%$ and $60 \%$ strains from nutrient agar and cultured in $\mathrm{BHI}$ and TSB respectively grown under similar conditions. However, no statistically significant difference was observed when the two methods were compared. The coaggregation index ranged from $12 \%$ to $74 \%$, with the best coaggregate activity observed when partnered with Streptococcus pyogenes (54\%-74\%). The study indicates the suitability of BHI and TSB medium for the cultivation of E. cloacae biofilms, however, temperature and incubation time significantly affect biofilm formation by these bacteria.
\end{abstract}


Keywords: Enterobacter cloacae; biofilm; growth medium; coaggregation; autoaggregation; temperature

\section{Introduction}

E. cloacae, a Gram negative bacterium, belongs to the family Enterobacteriaceae. The bacterium comprises part of the normal flora of the gastrointestinal tract of $40 \%-80 \%$ of the human population and is widely distributed in the environment [1]. The organism has also been isolated from food processing plants, fresh vegetables, rice, meat and meat products [2-4]. E. cloacae are capable of causing opportunistic infections including pneumonia, urinary tract, wound, skin and soft tissue, ophthalmic and bloodstream infections, particularly catheter-related where it has been reported to form biofilms in dwelling catheters of hospital patients $[5,6]$.

Biofilms are defined as matrix-enclosed bacterial populations, which adhere to each other and to surfaces; observations have conclusively shown that biofilm bacteria predominate numerically and metabolically, in virtually all ecosystems and are difficult to eliminate [7]. Bacterial biofilms are known to be linked to medical conditions such as cystic fibrosis, periodontitis, and nosocomial infections from the use of catheters and prosthetic heart valves [8]. However, biofilm formation in food processing plants has also been documented; both pathogenic and food spoilage microorganisms have been isolated from such bacterial communities [9].

It is well known that bacteria, including foodborne pathogens grow predominantly as biofilms in most of their natural habitats, but also in food processing, catering and the domestic environment [10]. Biofilms may generate a persistent source of contamination, leading to serious hygienic problems and also economic losses due to food spoilage [11]. Poor sanitation of food-contact surfaces is believed to be an essential contributing factor of foodborne disease and development of bacterial biofilms. The formed biofilms are a source of cross contamination as cells will continuously detach and contaminate food once it passes over contaminated surfaces or through aerosols originating from contaminated equipment. This may seriously affect the quality and safety of the processed food and pose a potential risk to the consumer [12].

E. cloacae and other species of Enterobacter have been reported to cause foodborne illnesses through consumption of a variety of foods, including infant foods [2]. In our recent study, E. cloacae was reported to be the second most prevalent organism from ready-to-eat foods [4]; implying that the organism might be one of the emerging foodborne pathogens that can be endemic in food processing environments. Studies on the ability of E. cloacae to form biofilms have focused mostly on clinical isolates $[13,14]$ where authors have hypothesized that their ability to persist in these environments as well as their virulence, is a result of their capacity to colonize medical devices [14]. However, in the food industry, studies have demonstrated the ability of Cronobacter sakazakii to adhere to feeding bottles, feeding tubes and other food processing surfaces with sparse information on E. cloacae. Modern food processing supports and selects for biofilm forming bacteria on food-contact surfaces due to mass production, lengthy production cycles and vast surface areas for biofilm development [15]. Biofilm formation depends on an interaction between three main components: the bacterial cells, the 
attachment surface and the surrounding medium [16]. However, environmental factors such as $\mathrm{pH}$, temperature, osmolarity, $\mathrm{O}_{2}$ levels, nutrient composition and the presence of other bacteria also play important roles [17,18]. The integration of these influences ultimately determines the pattern and behavior of a given bacterium with respect to biofilm development [19]. Hence, biofilms are very diverse and unique, not just to the microorganism, but to the particular environment in which they are being formed. This makes in vitro characterization of biofilms difficult and requires the establishment of laboratory conditions that mimic the natural setting being studied. The ability of these organisms to form biofilms at ambient temperature $\left(25^{\circ} \mathrm{C}\right)$, which is mostly room temperature in tropical countries, implies that under favorable conditions, they may be able to adhere to kitchen utensils and other environments leading to cross-contamination of food processed in these areas. Therefore the present study aimed to determine the effects of temperature, nutrient content and incubation time on attachment and biofilm formation by E. cloacae strains at ambient $\left(25{ }^{\circ} \mathrm{C}\right)$ and body $\left(37{ }^{\circ} \mathrm{C}\right)$ temperature in BHI and TSB media; in an effort to ascertain the suitable biofilm growth conditions for this bacterium as a guide to its containment in the food industry. BHI was chosen as one of the nutrient-rich laboratory medium, and TSB a less-rich (compared to BHI) culture medium which are frequently used in biofilm investigation.

\section{Results and Discussion}

\subsection{Microtiter Adherence}

Tests were performed in triplicates on three occasions, the results averaged and standard deviations were calculated. The cut-off was defined as three standard deviations above the mean OD of the negative control (ODc) which contained broth only. The following criteria were used to classify the different adherent strength: $\mathrm{OD} \leq \mathrm{OD}_{\mathrm{C}}=$ non-adherent, $\mathrm{OD}_{\mathrm{C}}<\mathrm{OD} \leq\left(2 \times \mathrm{OD}_{\mathrm{C}}\right)=$ weakly adherent; $\left(2 \times \mathrm{OD}_{\mathrm{C}}\right)<\mathrm{OD} \leq\left(4 \times \mathrm{OD}_{\mathrm{C}}\right)=$ moderately adherent and $\left(4 \times \mathrm{OD}_{\mathrm{C}}\right)<\mathrm{OD}=$ strongly adherent [20]

E. cloacae isolates displayed four different biofilm phenotypes (non, weak, moderate and strong adherent) after incubation for $24 \mathrm{~h}$ in both BHI and TSB (Table 1). The optical density (OD) of non adherent (NA), weak adherent (WA), moderate adherent (MA) and strong adherent (SA) obtained when the bacteria were grown in BHI ranged from 0.359-0.486, 0.552-1.159, 1.092-2.14 and 2.192-4.22 respectively. On the other hand, the OD obtained when the bacteria were grown in TSB ranged from $0.352-0.618,0.62-1.583,1.25-2.414$ and $2.542-3.938$ for NA, WA, MA and SA respectively (Table 2). It was observed that all the strains $(100 \%)$ adhered to the well of the microtiter plate when incubated for $48 \mathrm{~h}$, irrespective of the growth medium (BHI or TSB) and incubation temperature (Table 1). On the other hand, adherence ability was demonstrated by $73 \%$ (22) and $60 \%$ (18) of the strains obtained from inoculums prepared in nutrient agar and grown in BHI and TSB respectively, compared to $90 \%$ (27) and $73 \%$ (22) prepared in nutrient broth grown in BHI and TSB respectively, when the plates were incubated at $25{ }^{\circ} \mathrm{C}$ for $24 \mathrm{~h}$ (Table 1). All the strains (100\%) from nutrient agar cultures grown in BHI were able to form biofilm when incubated at $37{ }^{\circ} \mathrm{C}$ for $24 \mathrm{~h}$ compared to 28 (93\%) from nutrient broth grown in BHI; no difference was noted from TSB cultures, as $93 \%$ of the strains from both nutrient agar and broth formed biofilm (Table 1). However, no statistical significance ( $p$-value $>0.05)$ was observed when the two methods (agar and broth) were 
compared; thus it can be suggested that E. cloacae strains for biofilm formation assays may be cultivated either in broth or on solid medium.

Worthy of note is the fact that infecting bacteria are often surface-associated, and their cell surface can therefore be expected to be more similar to that of bacteria grown on solid medium than to that found grown in liquid media [13]. Bacterial cells grown on solid medium differ in expression of cell-associated molecules compared to those grown in liquid medium [20,21]. Probably the presence of slime layers that are regarded as soft polyelectrolyte layers surrounding the bacteria decreases the energy barrier due to electrostatic repulsion in the interaction of the organisms with negatively charged substrata and, thus, plays an important role in their adhesion [21]. In their study, Kiers et al. [21] found that cell surface softness of Staphylococcus epidermidis first grown on agar medium increased by a factor of two, compared to the cell surface softness for the strains grown in liquid medium. Therefore, preparation of the inoculum from broth or agar may directly influence the biofilm production, since adhesion is the first step in biofilm formation.

It was also noted that a good number of strains grown in nutrient broth, $90 \%$ and $73 \%$ cultured in BHI and TSB respectively were able to form biofilm, in contrast to $73 \%$ and $60 \%$ strains prepared from agar grown under similar conditions. However, no statistical significance was observed $(p>0.005)$ when the two methods were compared.

Composition of the medium has been documented to influence the ability of bacteria to produce biofilm under in vitro conditions; in particular the presence of glucose in the growth medium (i.e., standard TSB medium commonly contains $0.25 \%$ glucose) has been reported to enhance biofilm formation [22]. Some studies have shown preference for BHI to TSB, although some strains of Staphylococcus, Vibrio and Pseudomonas species have been reported to produce greater biofilm quantities in TSB while others do so in BHI [22,23]. The present study compared the two growth media and observed no statistical significance $(p>0.005)$. However, a slightly higher number of E. cloacae strains grown on BHI demonstrated the ability to adhere to the wells of the microtitre plate, implying that although both BHI and TSB media could support the development of E. cloacae biofilms in vitro, some strains will produce strong biofilms on BHI than TSB. These findings are in agreement with other studies $[17,24]$, which found that supplementation (enriching) of TSB medium with glucose increased the ability of Staphylococci to form biofilms, while Knobloch et al. [25] recommended the use of the two media to confirm a biofilm positive isolate.

All $(100 \%)$ of the E. cloacae strains demonstrated adherence characteristics at the low temperature of $25{ }^{\circ} \mathrm{C}$ when incubated for $48 \mathrm{~h}$ in comparison to the range of $60 \%-90 \%$ of the strains that had the same characteristics when incubated for $24 \mathrm{~h}$ only; the range increased with high temperatures $\left(37{ }^{\circ} \mathrm{C}\right)$ where $93 \%-100 \%$ of the strains demonstrated the adherence ability when incubated for $24 \mathrm{~h}$ (Table 1). Statistical significant adherence was observed $(p<0.005)$ when the two incubation periods were compared, which may imply that long incubation times and high temperatures influence biofilm formation.

Previous works have indicated that temperature, nutrients and other components in media affect attachment of microorganisms to surfaces of various materials [26,27]. The present study observed strong biofilms from plates incubated at $37{ }^{\circ} \mathrm{C}$ (Table 1). This could be attributed to the fast growth rate of the bacteria at higher temperatures [23]. Similarly, Iversen et al. [27] reported strong adherence of their test bacteria at high temperatures $\left(>40^{\circ} \mathrm{C}\right)$. 
Table 1. The effects of temperature, incubation time and growth medium on the biofilm formation of E. cloacae isolates.

\begin{tabular}{|c|c|c|c|c|c|c|c|c|c|c|c|c|c|c|c|c|}
\hline \multirow{4}{*}{$\begin{array}{c}\text { B. } \\
\text { phenotype }\end{array}$} & \multicolumn{16}{|c|}{ Parameters number (\%) } \\
\hline & \multicolumn{4}{|c|}{ BHI $^{\text {a }}$} & \multicolumn{4}{|c|}{ TSB $^{\text {a }}$} & \multicolumn{4}{|c|}{$\mathrm{BHI}^{\mathrm{b}}$} & \multicolumn{4}{|c|}{ TSB $^{\text {b }}$} \\
\hline & \multicolumn{2}{|c|}{$24 \mathrm{~h}$} & \multicolumn{2}{|c|}{$48 \mathrm{~h}$} & \multicolumn{2}{|c|}{$24 \mathrm{~h}$} & \multicolumn{2}{|c|}{$48 \mathrm{~h}$} & \multicolumn{2}{|c|}{$24 \mathrm{~h}$} & \multicolumn{2}{|c|}{$48 \mathrm{~h}$} & \multicolumn{2}{|c|}{$24 \mathrm{~h}$} & \multicolumn{2}{|c|}{$48 \mathrm{~h}$} \\
\hline & $25^{\circ} \mathrm{C}$ & $37^{\circ} \mathrm{C}$ & $25^{\circ} \mathrm{C}$ & $37^{\circ} \mathrm{C}$ & $25^{\circ} \mathrm{C}$ & $37^{\circ} \mathrm{C}$ & $25^{\circ} \mathrm{C}$ & $37^{\circ} \mathrm{C}$ & $25^{\circ} \mathrm{C}$ & $37^{\circ} \mathrm{C}$ & $25^{\circ} \mathrm{C}$ & $37^{\circ} \mathrm{C}$ & $25^{\circ} \mathrm{C}$ & $37^{\circ} \mathrm{C}$ & $25^{\circ} \mathrm{C}$ & $37^{\circ} \mathrm{C}$ \\
\hline NA & $8(27)$ & 0 & 0 & 0 & $12(40)$ & $2(7)$ & 0 & 0 & $3(10)$ & $2(7)$ & 0 & 0 & $8(27)$ & $2(7)$ & 0 & 0 \\
\hline WA & $18(60)$ & $10(33)$ & $10(33)$ & $5(17)$ & $14(47)$ & $17(57)$ & $18(60)$ & $4(13)$ & $20(67)$ & $11(37)$ & $12(40)$ & $4(13)$ & $19(63)$ & $14(47)$ & $6(20)$ & $2(7)$ \\
\hline MA & $4(13)$ & $18(60)$ & $16(53)$ & 0 & $4(13)$ & $10(33)$ & $11(37)$ & $10(33)$ & $7(23)$ & $14(47)$ & $15(50)$ & $9(30)$ & $3(10)$ & $11(37)$ & $16(53)$ & $11(37)$ \\
\hline SA & 0 & $2(7)$ & $4(13)$ & $25(83)$ & 0 & $1(3)$ & $1(3)$ & $16(53)$ & 0 & $3(10)$ & $3(10)$ & $17(57)$ & 0 & $3(10)$ & $8(27)$ & $17(57)$ \\
\hline T. adh. & 22 & 30 & 30 & 30 & 18 & 28 & 30 & 30 & 27 & 28 & 30 & 30 & 22 & 28 & 30 & 30 \\
\hline$(\%)$ & (73) & $(100)$ & $(100)$ & $(100)$ & (60) & (93) & $(100)$ & $(100)$ & $(90)$ & (93) & $(100)$ & $(100)$ & (73) & (93) & $(100)$ & (100) \\
\hline
\end{tabular}

BHI, brain heart infusion broth; TSB, tryptic soya broth; NA, non adherent; WA, weak adherent; MA, moderate adherent; SA, strong adherent; T. dh., total adherent; B. phenotype, biofilm phenotype; BHI ${ }^{\text {a }}$, colonies from Nutrient agar and grown in BHI broth; TSB ${ }^{\text {a }}$, colonies from Nutrient agar and grown in TS broth; BHI ${ }^{\mathrm{b}}$, inoculums from Nutrient broth and grown in BHI; $\mathrm{TSB}^{\mathrm{b}}$, inoculums from Nutrient broth and grown in TSB.

Table 2. The mean optical densities and standard deviations of the different biofilm phenotypes.

\begin{tabular}{|c|c|c|c|c|c|c|c|c|}
\hline \multirow{3}{*}{ Parameters } & \multicolumn{8}{|c|}{ Biofilm formation } \\
\hline & \multicolumn{2}{|c|}{ Non-adherent } & \multicolumn{2}{|c|}{ Weakly adherent } & \multicolumn{2}{|c|}{ Moderately adherent } & \multicolumn{2}{|c|}{ Strongly adherent } \\
\hline & OD range & $\begin{array}{c}\text { Mean } \\
\mathrm{OD} \pm \mathrm{SD}\end{array}$ & OD range & $\begin{array}{c}\text { Mean } \\
\mathbf{O D} \pm \mathbf{S D}\end{array}$ & OD range & $\begin{array}{c}\text { Mean } \\
\mathbf{O D} \pm \mathrm{SD}\end{array}$ & OD range & $\begin{array}{c}\text { Mean } \\
\mathrm{OD} \pm \mathrm{SD}\end{array}$ \\
\hline $25^{\circ} \mathrm{C} \mathrm{BHI}(24 \mathrm{~h})^{\mathrm{a}}$ & $0.448-0.486$ & $00.470 \pm 0.02$ & $0.572-0.990$ & $0.733 \pm 0.13$ & $1.30-2.14$ & $1.406 \pm 0.15$ & ND & ND \\
\hline $25^{\circ} \mathrm{C} \mathrm{BHI}(48 \mathrm{~h})^{\mathrm{a}}$ & ND & ND & $0.611-1.06$ & $0.875 \pm 0.13$ & $1.12-2.01$ & $1.344 \pm 0.25$ & $2.192-2.769$ & $2.543 \pm 0.39$ \\
\hline $25^{\circ} \mathrm{C}$ TSB $(24 h)^{a}$ & $0.352-0.618$ & $0.512 \pm 0.08$ & $0.626-1.131$ & $0.785 \pm 0.15$ & $1.365-1.458$ & $1.405 \pm 0.07$ & ND & ND \\
\hline $25^{\circ} \mathrm{C}$ TSB $(48 \mathrm{~h})^{\mathrm{a}}$ & ND & ND & $0.625-1.237$ & $0.984 \pm 0.18$ & $1.625-1.789$ & $1.507 \pm 0.231$ & ND & ND \\
\hline $37^{\circ} \mathrm{C} \mathrm{BHI}(24 \mathrm{~h})^{\mathrm{a}}$ & ND & ND & $0.590-1.074$ & $0.885 \pm 0.12$ & $1.164-2.022$ & $1.504 \pm 0.34$ & $2.224-3.327$ & $2.775 \pm 0.77$ \\
\hline $37^{\circ} \mathrm{C} \mathrm{BHI} \mathrm{(48} \mathrm{h)}{ }^{\mathrm{a}}$ & ND & ND & $0.580-0.784$ & $1.872 \pm 0.32$ & $1.331-2.13$ & $1.872 \pm 0.32$ & $2.35-4.22$ & $3.034 \pm 0.62$ \\
\hline $37^{\circ} \mathrm{C} \operatorname{TSB}(24 \mathrm{~h})^{\mathrm{a}}$ & $0.421-0.464$ & $0.442 \pm 0.03$ & $0.662-1.081$ & $0.861 \pm 0.169$ & $1.297-1.997$ & $1.591 \pm 0.199$ & ND & ND \\
\hline $37^{\circ} \mathrm{C} \operatorname{TSB}(48 \mathrm{~h})^{\mathrm{a}}$ & ND & ND & $0.988-1.583$ & $1.483 \pm 0.493$ & $1.93-2.485$ & $2.149 \pm 0.190$ & $2.556-3.635$ & $2.955 \pm 0.503$ \\
\hline
\end{tabular}


Table 2. Cont.

\begin{tabular}{|c|c|c|c|c|c|c|c|c|}
\hline \multirow{3}{*}{ Parameters } & \multicolumn{8}{|c|}{ Biofilm formation } \\
\hline & \multicolumn{2}{|c|}{ Non-adherent } & \multicolumn{2}{|c|}{ Weakly adherent } & \multicolumn{2}{|c|}{ Moderately adherent } & \multicolumn{2}{|c|}{ Strongly adherent } \\
\hline & OD range & $\begin{array}{c}\text { Mean } \\
\mathrm{OD} \pm \mathrm{SD}\end{array}$ & OD range & $\begin{array}{c}\text { Mean } \\
\text { OD } \pm \text { SD }\end{array}$ & OD range & $\begin{array}{c}\text { Mean } \\
\mathrm{OD} \pm \mathrm{SD}\end{array}$ & OD range & $\begin{array}{c}\text { Mean } \\
\mathrm{OD} \pm \mathrm{SD}\end{array}$ \\
\hline $25^{\circ} \mathrm{C}$ BHI $(24 \mathrm{~h})^{b}$ & $0.359-0.462$ & $0.420 \pm 0.05$ & $0.565-1.083$ & $0.832 \pm 0.14$ & $1.098-1.988$ & $1.509 \pm 0.340$ & ND & ND \\
\hline $25^{\circ} \mathrm{C} \mathrm{BHI}(48 \mathrm{~h})^{\mathrm{b}}$ & ND & ND & $0.729-1.048$ & $0.855 \pm 0.13$ & $1.436-2.144$ & $1.728 \pm 0.584$ & $2.253-3.24$ & $2.660 \pm 1.13$ \\
\hline $37^{\circ} \mathrm{C}$ BHI $(24 \mathrm{~h})^{b}$ & $0.44-0.481$ & $0.460 \pm 0.02$ & $0.552-1.111$ & $0.803 \pm 0.17$ & $1.123-2.039$ & $1.577 \pm 0.36$ & $2.405-3.27$ & $2.837 \pm 0.61$ \\
\hline $37^{\circ} \mathrm{C}$ BHI $(48 \mathrm{~h})^{\mathrm{b}}$ & ND & ND & $1.01-1.159$ & $1.074 \pm 0.06$ & $1.392-2.129$ & $1.697 \pm 0.24$ & $2.247-3.805$ & $2.93 \pm 0.546$ \\
\hline $25^{\circ} \mathrm{C}$ TSB $(24 \mathrm{~h})^{\mathrm{b}}$ & $0.421-0.559$ & $0.508 \pm 0.04$ & $0.62-1.117$ & $0.834 \pm 0.16$ & $1.319-1.774$ & $1.548 \pm 0.22$ & ND & ND \\
\hline $25^{\circ} \mathrm{C}$ TSB $(48 \mathrm{~h})^{\mathrm{b}}$ & ND & ND & $0.711-1.066$ & $1.034 \pm 0.18$ & $1.364-2.414$ & $1.706 \pm 0.36$ & $2.568-3.382$ & $2.929 \pm 0.36$ \\
\hline $37^{\circ} \mathrm{C}$ TSB $(24 h)^{b}$ & $0.503-0.535$ & $0.519 \pm 0.2$ & $0.623-1.153$ & $0.877 \pm 0.2$ & $1.561-2.413$ & $1.802 \pm 0.2$ & $2.542-2.66$ & $2.601 \pm 0.08$ \\
\hline $37^{\circ} \mathrm{C}$ TSB $(48 \mathrm{~h})^{\mathrm{b}}$ & ND & ND & $0.841-1.076$ & $0.958 \pm 1.66$ & $1.25-2.19$ & $1.831 \pm 0.54$ & $2.612-3.938$ & $3.261 \pm 0.54$ \\
\hline
\end{tabular}

OD, optical density; SD, standard deviation; ND, not determined; ${ }^{\text {a }}$, colonies from Nutrient agar; ${ }^{\mathrm{b}}$, inoculums from Nutrient broth; BHI, brain heart infusion broth; TSB, tryptic soy broth.

Table 3. Coaggregation indices of selected biofilm forming E. cloacae strains with seven different reference strains partners.

\begin{tabular}{|c|c|c|c|c|c|c|c|c|c|}
\hline \multirow{3}{*}{$\begin{array}{c}\text { Isolate } \\
\text { (biofilm } \\
\text { phenotype) }\end{array}$} & \multirow{3}{*}{ \%Autoagg. } & \multicolumn{8}{|c|}{ Coaggregation indices (\%) } \\
\hline & & \multicolumn{8}{|c|}{ Partner strains } \\
\hline & & Range $\%$ & $\begin{array}{c}\text { S. aureus } \\
\text { NCTC } 6571\end{array}$ & $\begin{array}{l}\text { S. pyogenes A } \\
\text { ATCC } 49399\end{array}$ & $\begin{array}{c}S . \text { Typhimurium } \\
\text { ATCC } 13311\end{array}$ & $\begin{array}{c}\text { P. aeruginosa } \\
\text { ATCC } 15442\end{array}$ & $\begin{array}{c}\text { P. shigelloides } \\
\text { ATCC } 51903\end{array}$ & $\begin{array}{l}\text { A. hydrophila } \\
\text { ATCC } 35654\end{array}$ & $\begin{array}{c}\text { S. sonnei } \\
\text { ATCC } 29930\end{array}$ \\
\hline EC 52-2 (NA) & 27 & $55-66$ & 55 & 66 & 63 & 55 & 64 & 61 & 58 \\
\hline EC 205 (NA) & 38 & $54-66$ & 54 & 63 & 66 & 62 & 62 & 64 & 61 \\
\hline EC 12-2 (WA) & 45 & $56-69$ & 69 & 69 & 59 & 56 & 68 & 69 & ND \\
\hline EC 70-2 (MA) & 89 & $12-70$ & 57 & 61 & 29 & 70 & 12 & 64 & 56 \\
\hline EC 89-2 (MA) & 30 & $31-62$ & 43 & 54 & 62 & 40 & 53 & 31 & 23 \\
\hline EC 235 (WA) & 34 & $65-74$ & 68 & 74 & 74 & 72 & 72 & 65 & 69 \\
\hline
\end{tabular}

NA, non adherent; WA, weak adherent; MA, moderate adherent; Autoagg, autoaggregation. 
Contrary to these findings were the observations by Di Bonaventura et al. [18] who reported a higher biofilm production at a lower temperature $\left(32^{\circ} \mathrm{C}\right)$ than the higher temperatures of $37{ }^{\circ} \mathrm{C}$; which may further suggest that biofilm formation varies with temperature and organism. Hence from the findings of the current study it can be deduced that E. cloacae strains will produce strong biofilms at higher temperatures.

\subsection{The Capability of E. cloacae Strains to Autoaggregate and Coaggregate with Partner Organisms}

All E. cloacae strains were able to coaggregate with the seven partner strains; the coaggregation index ranged from $12 \%-74 \%$ with best coaggregate activity observed when partnered with Streptococcus pyogenes (54\%-74\%) (Table 3). It was also noted that most of the strains which weakly adhered to the wells had a slightly higher coaggregation index range of $56 \%-74 \%$ followed by moderate adherent $12 \%-70 \%$ and the least was non- adherent with $54 \%-66 \%$ (Table 3). Of particular interest was a weakly adherent isolate, EC 235 which demonstrated the strongest coaggregation with all the partners. On the other hand, all the strains were able to adhere to each other, with autoaggregation range of $27 \%-89 \%$ (Table 3 ).

First recognized between bacterial isolates from human dental plague, coaggregation is the highly specific recognition and adhesion of different bacterial species to one another by specific molecules. Coaggregation in biofilms is important in development of mix-culture biofilms; it enables cells to withstand the highly changing environment, which on the other hand can adversely affect mono-dispersed cells. The results of this study revealed that E. cloacae isolates which weakly adhered to the microtiter plate demonstrated the strongest coaggregation with all the seven partner strain; these findings suggest the possibility of these strains to act as bridging organisms in multi-generic biofilms due to their ability to coaggregate with diverse coaggregating partners. Such bridging organisms are believed to carry complementary receptors recognized by functionally similar adhesins on cells from distinct genera [28]. Figure 1 shows the scanning electron micrographs of E. cloacae autoaggregates and its coaggregate partner Pseudomonas aeruginosa ATCC 15442. The SEM graphics of coaggregate assay demonstrated strong coaggregation with $P$. aeruginosa. It was also observed that E. cloacae strains coaggregated with organisms important in food spoilage and/or intoxications, i.e., S. aureus, $S$. Typhimurium, Shigella sonnei and P. aeruginosa implying that E. cloacae in food processing plants can enhance the bridging of organisms in multi-generic biofilms.

\section{Experimental}

\subsection{Bacterial Strains}

Bacterial strains used in the study consist of E. cloacae previously isolated from various food sources [4] and reference strains: S. pyogenes A ATCC 49399, Plesiomonas shigelloides ATCC 51903, P. aeruginosa ATCC 15442, S. Typhimurium ATCC 13311, Aeromonas hydrophila ATCC 35654 and S. sonnei ATCC 29930. These strains have been reported to form biofilms [29-32]; and were also available in our laboratory at the time of the experiments. 
Figure 1. Scanning electron micrographs of an autoaggregate and coaggregate biofilm of E. cloacae and its coaggregate partner P. aeruginosa ATCC 15442 (a) strong adherent autoaggregate; (b) coaggregate of E. cloacae and partner P. aeruginosa ATCC 15442.

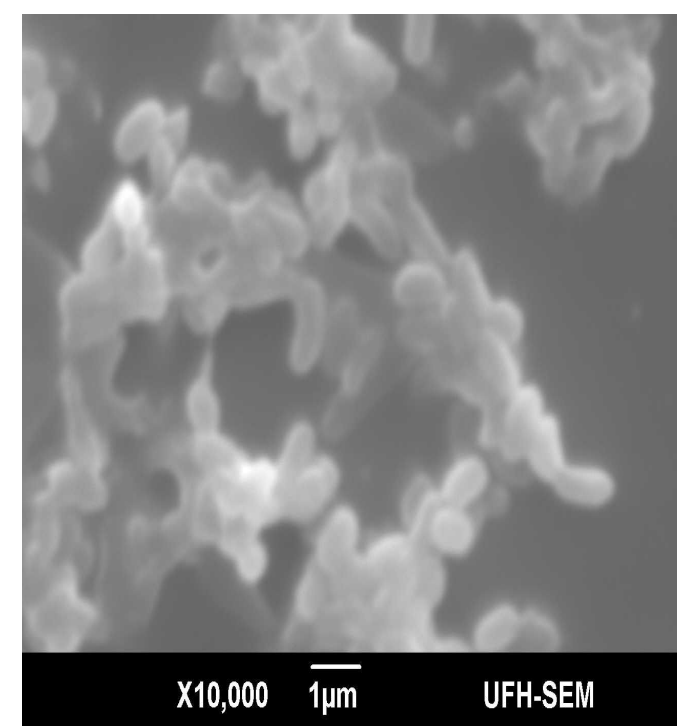

(a)

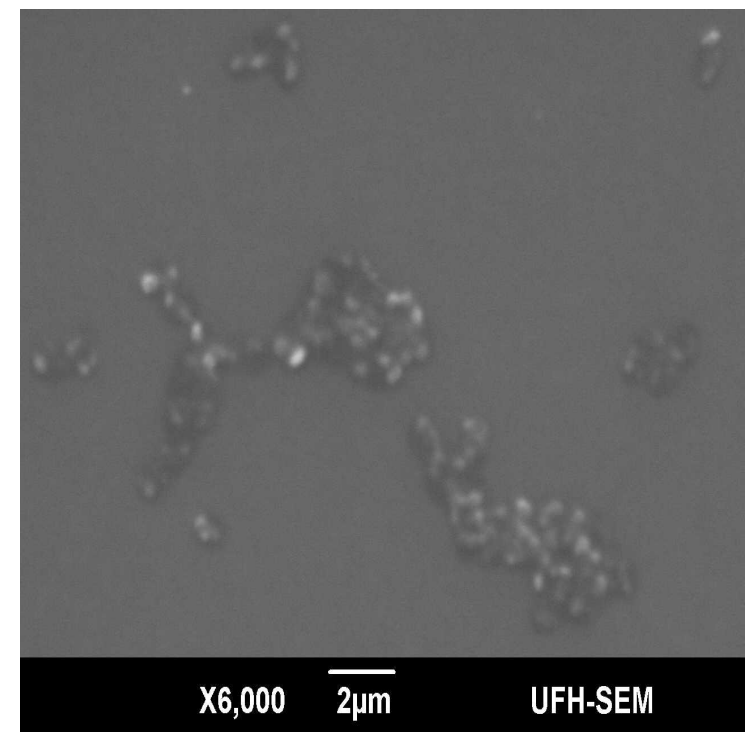

(b)

\subsection{Microtiter Plate Assay}

E. cloacae isolates were screened for their adherence to polystyrene microtiter plate wells following 24 and $48 \mathrm{~h}$ incubation at $25{ }^{\circ} \mathrm{C}$ or $37{ }^{\circ} \mathrm{C}$, in BHI and TSB. The method previously described by Nyenje et al. [33] was employed which made use of the agar and broth techniques; for the agar method, E. cloacae isolates were cultured on Nutrient agar (Oxoid, Basingstoke, England) and plates incubated at $37^{\circ} \mathrm{C}$ for $24 \mathrm{~h}$. Few single colonies were suspended in sterile saline to a turbidity standard comparable to a $0.5 \mathrm{McF}$ arland. The suspension was vortexed for $1 \mathrm{~min}$ from which $20 \mu \mathrm{L}$ was pipetted into a 96-well U-bottomed microtiter plate (Greiner Bio-one GmbH, Frickenhausen, Germany) containing $180 \mu \mathrm{L}$ of BHI or TSB (Oxoid). With the inoculum for broth technique, isolates were grown in Nutrient broth (Oxoid), incubated for $24 \mathrm{~h}$ at $37{ }^{\circ} \mathrm{C}$. Subsequently, the bacterial suspension was diluted 1:100 in BHI or TSB; an aliquot of $200 \mu \mathrm{L}$ of diluted bacterial suspension was added to each well. The negative control wells contained $200 \mathrm{~mL}$ of broth only per well. The plates were incubated aerobically at different temperatures $\left(25^{\circ} \mathrm{C}\right.$ and $\left.37^{\circ} \mathrm{C}\right)$ for 24 and $48 \mathrm{~h}$. At the end of incubation period, the wells were carefully aspirated and washed three times with $200 \mu \mathrm{L}$ of sterile normal saline to remove the unbound bacteria. The plates were left to dry overnight, fixed with hot air at $65{ }^{\circ} \mathrm{C}$ for $1 \mathrm{~h}$, and the wells were stained with $150 \mu \mathrm{L}$ of $1 \%$ crystal violet for $30 \mathrm{~min}$. The plates were carefully rinsed off under running tap water to remove excess stain, left to dry at room temperature before resolubilizing the dye bound cells with $150 \mu \mathrm{L}$ of $33 \%$ (v/v) glacial acetic acid. The optical density (OD) of each well was measured at $595 \mathrm{~nm}$ using a microtiter plate reader (SynergyMx, Biotek ${ }^{\mathrm{TM}}$ Winooski, VT, USA). Reference strains of $P$. aeruginosa ATCC 15442 and S. aureus NCTC 6571 were used as positive controls because they have been widely reported to form biofilms in various environments [29-32]. 


\subsection{Autoaggregation and Coaggregation Assays}

A representative of the different biofilm phenotypes were examined for their ability to coaggregate with the following reference strains: $S$. aureus NCTC 6571, S. pyogenes A ATCC 49399, $S$. Typhimurium ATCC 13311, P. aeruginosa ATCC 15442, P. shigelloides ATCC 51903, A. hydrophila ATCC 35654, S. sonnei ATCC 29930. The individual strain was grown in $20 \mathrm{~mL}$ of BHI broth at $37^{\circ} \mathrm{C}$, harvested after $48 \mathrm{~h}$ and washed twice in $3 \mathrm{mM} \mathrm{NaCl}$ containing $0.5 \mathrm{mM} \mathrm{CaCl}_{2}$. Subsequently, the cells were re-suspended in the same solution ( $3 \mathrm{mM} \mathrm{NaCl}$ containing $0.5 \mathrm{mM} \mathrm{CaCl} 2$ ), centrifuged at $650 \times \mathrm{g}$ for $2 \mathrm{~min}$ and the supernatant discarded; the OD of the cell suspension used for coaggregation assay was adjusted to 0.3 at a wavelength of $660 \mathrm{~nm}$, using an automated spectrophotometer (Optima Scientific V-1200, Cambridge, UK). Equal volumes of the cell suspension (1 mL each) of E. cloacae and the coaggregating partners were mixed and the $\mathrm{OD}\left(\mathrm{OD}_{\mathrm{Tot}}\right)$ immediately read at $660 \mathrm{~nm}$ before incubation at room temperature for $2 \mathrm{~h}$. Subsequently, the tubes were centrifuged at 2,000 rpm for $2 \mathrm{~min}$ and the $\mathrm{OD}$ of the supernatant $\left(\mathrm{OD}_{\mathrm{s}}\right)$ measured at the same wavelength $(660 \mathrm{~nm})$ [20]. The degree of coaggregation of the paired isolates was determined using the equation:

$$
\% \text { coaggregation }=\left(\mathrm{OD}_{\mathrm{Tot}}-\mathrm{OD}_{\mathrm{s}}\right) \times 100 / \mathrm{OD}_{\mathrm{Tot}}
$$

For autoaggregation assay, the individual bacterial suspension adjusted to an OD of 0.3 was incubated at room temperature for $1 \mathrm{~h}$, centrifuged at 2,000 rpm for $2 \mathrm{~min}$ and the OD of the supernatant was measured at $660 \mathrm{~nm}$. The degree of autoaggregation was calculated as follows:

$$
\% \text { autoaggregation }=\left(\mathrm{OD}_{0}-\mathrm{OD}_{60}\right) \times 100 / \mathrm{OD}_{0}
$$

$\mathrm{OD}_{0}$ refers to the initial $\mathrm{OD}$ of the organism, and $\mathrm{OD}_{60}$ is the $\mathrm{OD}$ of the supernatant after $60 \mathrm{~min}$ of incubation.

\subsection{Characterization of Biofilm Formation Using Scanning Electron Microscope}

To evaluate the architecture of the formed biofilms, SEM was used in accordance with the method previously described by Nyenje et al. [33]. Briefly, the isolates were grown on a microscope cover slip $(22 \times 22 \mathrm{~mm})$ in a Petri-dish half-filled with BHI broth and incubated at $37{ }^{\circ} \mathrm{C}$ for $72 \mathrm{~h}$. For the coaggregation assay, the partner isolate was added after $1 \mathrm{~h}$ of incubation. At the end of the incubation, the cover slips were washed three times with normal saline before fixing with $2.5 \%(\mathrm{w} / \mathrm{v})$ glutaraldehyde solution for $1 \mathrm{~h}$. Subsequently, the samples were dehydrated in a series of 20,40, 60, 80 and $99.5 \%$ ethanol solution for $30 \mathrm{~min}$ in each concentration before post fixing in $1 \%$ osmium tetroxide $\left(\mathrm{OsO}_{4}\right)$. The samples were critical point-dried using $\mathrm{CO}_{2}$ and sputter-coated with gold palladium using an Elko 1B.3 ion coater before viewing with the SEM (Japan Electron Optical Laboratories JSM-6390LV, Tokyo, Japan).

\section{Statistical Analysis}

Statistical analysis was performed using SPSS version 19. One way ANOVA followed by Turkey's post hoc test was used to compare the agar and broth methods, BHI and TSB liquid media. The incubation temperatures and periods were also compared; the mean difference was considered significant at $p<0.05$. 


\section{Conclusions}

This study demonstrated that E. cloacae readily form biofilms on plastic surfaces, which are nowadays frequently used in food-processing environments, raising a great concern for the food industry as organisms in biofilms are difficult to eliminate, hence creating a reservoir for cross contamination. The study also indicated the suitability of BHI and TSB medium for the cultivation of E. cloacae biofilm however, temperature and incubation time significantly affected biofilm formation by these bacteria.

\section{Acknowledgments}

The authors are thankful to the Govan Mbeki Research and Development Centre, University of Fort Hare, South Africa for funding.

\section{Conflict of Interest}

The authors declare no conflict of interest.

\section{References}

1. Paterson, D.L.; Rossi, F.; Baquero, F.; Hsueh, P.R.; Woods, G.L.; Satishchandran, V.; Snyder, T.A.; Harvey, C.M.; Teppler, H.; Di Nubile, M.J. In vitro susceptibilities of aerobic and facultative Gram-negative bacilli isolated from patients with intra-abdominal infections worldwide: the 2003 study for monitoring antimicrobial resistance trends (SMART). J. Antimicrob. Chemother. 2005, 55, 965-970.

2. Shaker, R.; Osaili, T.; Al-Omary, W.; Jaradat, Z.; Al-Zuby, M. Isolation of Enterobacter sakazakii and other Enterobacter species from food and food production environments. Food Cont. 2007, 18, 1241-1245.

3. Haryani, Y.; Tunung, R.; Chai, L.C.; Lee, H.Y.; Tang, S.Y.; Son, R. Characterization of Enterobacter cloacae isolated from street foods. ASEAN Food J. 2008, 15, 57-64.

4. Nyenje, M.E.; Odjadjare, C.E.; Tanih, N.F.; Green, E.; Ndip, R.N. Foodborne pathogens recovered from ready-to-eat foods from roadside cafeterias and retail outlets in Alice, Eastern Cape Province, South Africa: public health implications. Int. J. Environ. Res. Public Health 2012, 9, 2608-2619.

5. Storti, A. Pizzolitto, A.C, Pizzolitto E.L. Detection of mixed microbial biofilms on central venous catheters removed from intensive care unit patients. Braz. J. Microbiol. 2005, 36, 275-280.

6. Mokracka, J.; Koczura, R.; Pawlowski, K.; Kaznowski, A. Resistance patterns and integron cassette arrays of Enterobacter cloacae complex strains of human origin. J. Med. Microbiol. 2011, 60, 737-743.

7. Donlan, R.M. Biofilms: microbial life on surfaces. Emerg. Infect. Dis. 2002, 8, 881-890.

8. Delle-Bovi, R.J.; Smits, A.; Pylypiw, H.M. Rapid method for the determination of total monosaccharide in Enterobacter cloacae strains using Fourier Transform Infrared Spectroscopy. Am. J. Analytical Chem. 2011, 2, 212-216. 
9. Schlegelová, J.; Babák, V.; Holasová, M.; Konstantinová, L.; Necidová, L.; Šišák, F.; Vlková, H.; Roubal, P.; Jaglic, Z. Microbial contamination after sanitation of food contact surfaces in dairy and meat processing plants. Czech J. Food Sc. 2010, 28, 450-461.

10. Kusumaningrum, H.D.; Riboldi, G.; Hazeleger, W.C.; R.R. Beumer, R.R. Survival of foodborne pathogens on stainless steel surfaces and cross-contamination to foods. Int. J. Food Microbiol. 2003, 85, 227-236.

11. Brooks, J.D.; Flint, S.H. Biofilms in the food industry: problems and potential solutions. Int. J. Food Sci. Technol. 2008, 43, 2163-2176.

12. Chmielewski, R.A.N.; Frank, J.F. Biofilm formation and control in food processing facilities. Compr. Rev. Food Sci. Food Safety 2003, 2, 22-32.

13. Donlan, R.M. Biofilms and device-associated infections. Emerg. Infect. Dis. 2001, 7, 277-281.

14. Revdiwala, S.; Rajdey, B.M.; Mulla, S. Characterization of bacterial etiologic agents of biofilm formation in medical devices in critical care setup. Crit. Care Res. Pract. 2012, 2012, 945805.

15. Lindsay, D.; von Holy, A. What food safety professionals should know about bacterial biofilms. Brit. Food J. 2006, 108, 27-37.

16. Van Houdt, R.; Michiels, C.W. Biofilm formation and the food industry, a focus on the bacterial outer surface. J. Appl. Microbiol. 2010, 109, 1117-1131.

17. Stepanovic, S.; Djukic, N.; Opavski, N.; Djukic, S. Significance of inoculum size in biofilm formation by Staphylococci. New Microbiol. 2003, 26, 129-132.

18. Di Bonaventura, G.; Stepanović, S.; Picciani, C.; Pompilio, A.; Piccolomini, R. Effects of environmental factors on biofilm formation by clinical Stenotrophomonas maltophilia isolates. Folia Microbiol. 2007, 52, 86-90.

19. Goller, C.C.; Romeo, T. Environmental influences on biofilm development. Curr. Topics Microbiol. Immunol. 2008, 322, 37-66.

20. Basson, A.; Flemming, L.A.; Chenia, H.Y. Evaluation of adherence, hydrophobicity, aggregation characteristics and biofilm development of Flavobacterium johnsoniae-like isolates from South African aquaculture systems. Microbial Ecol. 2007, 55, 1-14.

21. Kiers, P.J.; Bos, R.; van der Mei, H.C.; Busscher, H.J. The electrophoretic softness of the surface of Staphylococcus epidermidis cells grown in a liquid medium and on a solid agar. Microbiology 2001, 147, 757-762.

22. Stepanovic, S.; Vukovic, D.; Hola, V.; Bonaventura, G.; Djukic, S.; Cirkovic, I.; Ruzika, F. Quantification of biofilm in microtiter plates: overview of testing conditions and practical recommendations for assessment of biofilm production by Staphylococci. Apmis 2007, 115, 891-899.

23. Hoštacká, A.; Čižnár, I.; Štefkovičová, M. Temperature and $\mathrm{pH}$ affect the production of bacterial biofilm. Folia Microbiol. 2010, 55, 75-78.

24. Mathur, T.; Singhal, S.; Khan, S.; Upadhyay, D.J.; Fatma, T.; Rattan, A. Detection of biofilm formation among the clinical isolates of Staphylococci: an evaluation of three different screening methods. Ind. J. Med. Microbiol. 2006, 24, 25-29.

25. Knobloch, J.K.; Horstkotte, M.A.; Rohde, H.; Mack, D. Evaluation of different detection methods of biofilm formation in Staphylococcus aureus. J. Med. Microbiol. Immunol. 2002, 191, 101-106. 
26. Hood, S.K.; Zottola, E.A. Growth media and surface conditioning influence the adherence of Pseudomonas fragi, Salmonella Typhimurium, and Listeria monocytogenes cells to stainless steel. J. Food Protect. 1997, 60, 1034-1037.

27. Iversen, C.; Lane, M.; Forsythe, S.J. The growth profile, thermo-tolerance and biofilm formation of Enterobacter sakazakii grown in infant formula milk. Lett. Appl. Microbiol. 2004, 38, 378-382.

28. Malik, A.; Sakamoto, M.; Hanazaki, S.; Osawa, M.; Suzuki, T.; Tochigi, M.; Kakii, K. Coaggregation among nonflocculating bacteria isolated from activated sludge. Appl. Environ. Microbiol. 2003, 69, 6056-6063.

29. Hammer, K.A.; Carson, C.F., Rilley, T.V. Australia Government report for the Rural Industries Research and Development Corporation; RIRDC 05/115; Novasel Australia Pty Ltd: Crawley, Australia, 2005.

30. Qadri, F., Hossain, S.A., Ciznar, I., Haider, K., Ljungh, A., Wadstrom, T., Sack, D.A. Congo red binding and salt aggregation as indicators of virulence in Shigella species. J. Clin. Microbiol. 2007, 26, 1343-1348.

31. Bridier, A.; Dubois-Brissonnet, F.; Greub, G.; Thomas, V.; Briandet, R. Dynamics of the action of biocides in Pseudomonas aeruginosa biofilms. Antimicrob. Agents Chemother. 2011, 55, 2648-2654.

32. Díez-García, M., Capita, R., Alonso-Calleja C. Influence of serotype on the growth kinetics and the ability to form biofilms of Salmonella isolates from poultry. Food Microbiol. 2012, 31, 173-180.

33. Nyenje, M.E.; Green, E.; Ndip, R.N. Biofilm formation and adherence characteristics of Listeria ivanovii strains isolated from ready-to-eat foods in Alice, South Africa. Scientific World J. 2012, $2012,873909$.

Sample Availability: Samples of the compounds of the present study are available from the authors.

(C) 2013 by the authors; licensee MDPI, Basel, Switzerland. This article is an open access article distributed under the terms and conditions of the Creative Commons Attribution license (http://creativecommons.org/licenses/by/3.0/). 